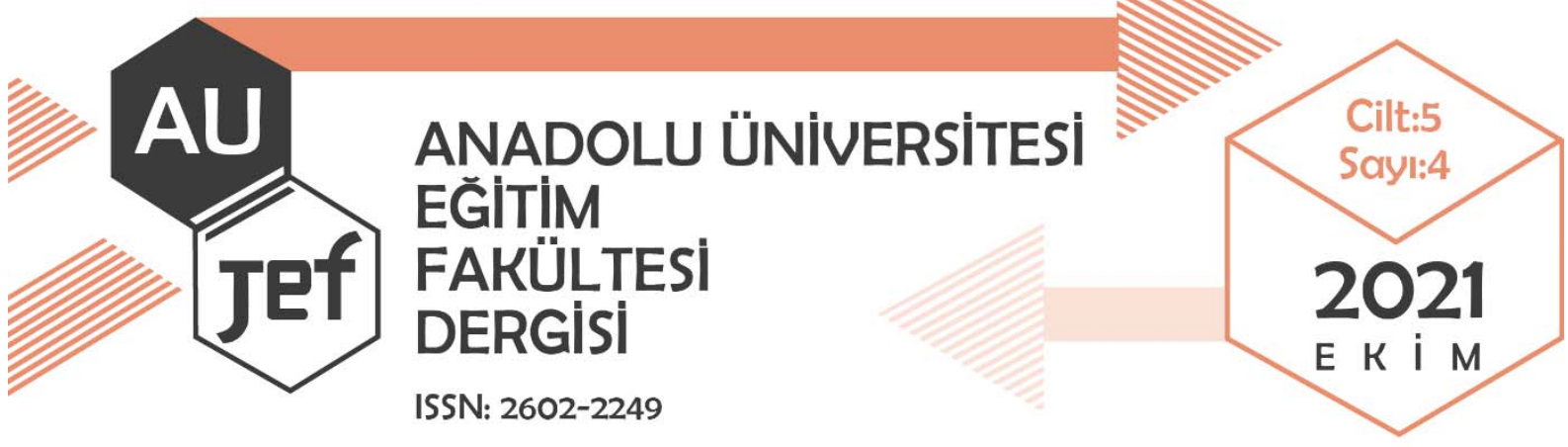

\title{
Göç ile Gelen Öğrencilerin Eğitim Sorunlarına İlişkin Öğretmen Görüşleri
}

\section{Teachers' Opinions About the Educational Problems of Migrant Students}

Dr. Fatih PALA ${ }^{1}$

Makale Türü: Araştırma Makalesi

Başvuru Tarihi: 23.09 .2020

Kabul Tarihi: 04.10.2021

Atıf İçin: Pala, F. (2021). Göç ile gelen öğrencilerin eğitim sorunlarına ilişkin öğretmen görüşleri. Anadolu Üniversitesi Eğitim Fakültesi Dergisi (AUJEF), 5(4), 347-365.

ÖZ: Bu çalışma, göç ile gelen öğrencilerin karşılaştığı eğitim sorunlara ilişkin öğretmen görüşlerini belirlemeyi amaçlamıştır. Çalışmada nitel araştırma desenlerinden durum çalışması kullanılmıştır. Araştırma İstanbul ili Sultanbeyli ilçesi sınırları içerisinde Milli Eğitim Bakanlığı'na bağlı bir ortaokulda yapılmıştır. Araştırmaya, kolay ulaşılabilir durum örneklemesi/uygun örnekleme yoluyla seçilen 35 öğretmen katılmıştır. Bu çalışmada, veri toplama aracı olarak araştırmacı tarafından hazırlanan yarı yapılandırılmış görüşme formu kullanılmıştır. Verilerin analizinde durum çalışmalarında sıkça kullanılan betimsel analiz yönteminden faydalanılmıştır. Araştırma sonucunda öğretmenler, göç ile öğrencilerin maddi, akademik, ailevi ve davranış olarak problemlerinin olduğunu belirtmişlerdir.

Anahtar sözcükler: Göç, öğrenci, eğitim sorunu, öğretmen görüşü.

\begin{abstract}
This study aimed to identify the opinions of the teachers about the educational problems faced by immigration students. The study is a case study, which is one of the qualitative research methods. The research was carried out in a secondary school affiliated with the Ministry of Education within the borders of Sultanbeyli district of Istanbul. 35 teachers selected through easy-access case sampling / proper sampling participated in the study. In this study, a semi-structured interview form prepared by the researcher was used as data collection tool. The descriptive analysis method, which is frequently used in case studies, was used to analyze the data. As a result of the research, teachers stated that immigration and students have problems in terms of material, academic, family and behavior.
\end{abstract}

Keywords: Migration, student, education problem, teacher opinion.

\footnotetext{
${ }^{1}$ Dr., Milli Eğitim Bakanlığ1, e-r-z-u-r-u-m-25@hotmail.com, ORCID: 0000-0003-1828-0461
} 


\section{GíRiş}

Geçmişten beri göç olgusu çeşitli tanımlarla ifade edilmektedir. Göç, kişinin dünyaya geldiği andan itibaren ölümüne kadar hayat mücadelesinde ona eşlik eden bir olgudur. Bu bağlamda göç, kişilerin hayatlarının her anında yüzleştiği bir durumdur. Türkçede göç olgusu; genel olarak bir topluluğun ya da bir grubun evini, hayat arkadaşları ile birlikte bulunduğu yerden başka bir yerlere taşınması, yani yaşadığı çevreyi değiştirmesi olayıdır (Çakır, 2011). Göç olgusu insanlık tarihi ile eş zamanlı olarak var olmuş ve insan yaşamını önemli ölçüde etkilemiştir. Modern dönemlerde göç, farklı zamanlarda farklı nedenlerle insanoğlu tarafından gerçekleştirilmiştir. Sanayi İnkılabı ile kentleşmede meydana gelen gelişim ve köyden kente göçe sebep olmuştur. Dünya savaşlarının toplumsal ve ekonomik zararları insanoğlunu farklı yerlere göçe zorlamıştır. İnsanlar, yaşadıkları çevrede var olan olumsuzluklardan kurtulmak yeni yerlerin faydalarından yararlanmak için göçe yönelmektedir (Çelik, 2006; İçduydu ve Ünalan, 1997; Taşc1, 2009).

Göç hareketleri, her geçen gün artış göstermektedir. Türkiye'de her y1l binlerce kişi farklı sebeplerden dolayı yaşadıkları yerlerden göç etmek zorunda kalmaktadır. Dünyada olduğu gibi Türkiye'de de göçün ana nedenleri arasında iktisadi, sosyokültürel, coğrafik, demografik ve siyasi nedenler yer almaktadır. Bu nedenlerden özellikle iktisadi olanı Türkiye'de göç eden kişileri yaşadığ 1 yerden başka yerlere taşınmaktadır. Bundan dolayı hem bölgesel hem de bireysel çapta gelir farkı, göç olgusunun önemli faktörü olduğu insanoğlu tarafindan kabul edilmiştir ( Yamak ve Yamak, 1999). Türkiye'de, 1940-1950 arasında şehir nüfusu oransal olarak genel nüfusun yarısı kadar değildi. Fakat şehirlerdeki nüfus 1950-1960 yıllarında genel nüfusun yarısını geçmiş durumdaydı. Teknolojinin kendini tarımda hissettirmesi ile köylerde işsizlik sorununu ortaya çıkmıştır. Bundan dolayı kırdan kente göç hareketleri yaşanmıştır. Göç hareketleri ile şehirlerde bazı çevresel ve toplumsal sorunlar ortaya çıkmıştır (Özcan, 1998; Tekeli, 1998).

Sonuç olarak, ülkemizdeki göç olgusu ülkenin sosyal ve iktisadi şeklini değiştiren en önemli unsurların başında gelir. Bu durumun oluşması tek bir nedene bağlı değildir, birden çok nedenin bu yapının oluşmasında etkili olmuştur. 1950‘den sonra Türkiye'de şehirleşme ve göç olgusu sosyal değişim sürecine paralel olarak çok fazla hız kazanmıştır. Türkiye açısından düşünüldügünde göç hareketinde 1950 ve 1980 yılların sonuna kadar etkili olmuştur. Özellikle bu yıllar arasında göç hareketinin yaşanmasında, siyasi, toplumsal, iktisadi gelişmeler etkili olmuştur ( Koyuncu, 2011; Y1ldırım, 2014).

\subsection{Türkiye'de Göç}

Göç olgusu geçmişten beri çeşitli sebeplerle var olan bir olgudur. Anadolu topraklarındaki göç hareketleri M.Ö. yıllara uzanmaktadır. Eski zamanlardan beri gerçekleşen göçler, yeryüzünde adaletsiz biçimde serpilmiş iktisadi imkânlardan faydalanma arzusunun bir sonucu olabildiği gibi çevresel zorluklar veya devlet gibi sosyal bir otoritenin gündeme getirdiği sürgünler, mecburi iskânlar ve savaşlar nedeniyle de varlığını göstermektedir ( Yenigül, 2005).

Türkiye Cumhuriyeti'nin kuruluşunun ilk yıllarında nüfusun çoğu köylerde ikamet etmekteydi. $\mathrm{Bu}$ durum zamanla değişime uğramıştır. Köy nüfusu zamanla azalarak yerini kent nüfusuna bırakmıştır. Bu durumun etkisi ise kent nüfusu köy nüfusunu geçmiştir. 1980'lerden sonra yaşanılan yerler arasında göç eden nüfus oranı \% 9'larda iken, 1990'larda \% 10 ve 2000'li yıllardan sonra yaklaşık olarak \%11 olmuştur. Belirtilen dönemlerde insanlar çeşitli sebeplerden dolayı farklı yerlere göç etmiştir (Güreşçi, 2010).

Anadolu Üniversitesi Ĕgitim Fakültesi Dergisi (AUJEF), 5(4), 347-365 
Tablo 1. 2019 Yılı Bölgeler Arası Sayısal Göç Bilgileri

\begin{tabular}{|c|c|c|c|c|}
\hline Bölgeler & $\begin{array}{c}\text { Bölgelerin } \\
\text { Aldığı Göç } \\
\text { Bilgileri }\end{array}$ & $\begin{array}{l}\text { Bölgelerin Net } \\
\text { Göç Bilgileri }\end{array}$ & $\begin{array}{l}\text { Bölgelerin Net Göç } \\
\text { Hızı Bilgileri }\end{array}$ & $\begin{array}{l}\text { Bölgelerin Verdiği } \\
\text { Göç Bilgileri }\end{array}$ \\
\hline Akdeniz & 240130 & 2867 & 0,27 & 237263 \\
\hline Batı Anadolu & 255357 & 52185 & 6,44 & 203172 \\
\hline Batı Karadeniz & 169437 & -46171 & $-9,85$ & 215608 \\
\hline Batı Marmara & 126488 & 13230 & 3,68 & 113258 \\
\hline Doğu Karadeniz & 95959 & -57318 & $-21,08$ & 153277 \\
\hline Doğu Marmara & 251226 & 49681 & 6,13 & 201545 \\
\hline Ege & 238962 & 32615 & 3,08 & 206347 \\
\hline $\begin{array}{l}\text { Güneydoğu } \\
\text { Anadolu }\end{array}$ & 168902 & -55391 & $-6,15$ & 224293 \\
\hline İstanbul & 498676 & 120371 & 7,79 & 378305 \\
\hline $\begin{array}{l}\text { Kuzeydoğu } \\
\text { Anadolu }\end{array}$ & 79418 & -35488 & -16 & 114906 \\
\hline Orta Anadolu & 114039 & -34653 & $-8,47$ & 148692 \\
\hline $\begin{array}{l}\text { Ortadoğu } \\
\text { Anadolu }\end{array}$ & 106742 & -41928 & $-10,61$ & 148670 \\
\hline
\end{tabular}

\subsection{Göç Türleri}

Literatürde göç türleri iç ve dış göçler olarak ikiye ayrılmaktadır. Milli sınırları içerisinde kentten kente, kentten kıra, kırdan kente, kırdan kıra çeşitli sebeplerle yerleşmek amaciyla gerçekleştirilen nüfus hareketine iç göç; ülkelerin milli sınırlarını aşarak, mili sınırlar içinden dışarıya ya da mili sınırlar dışında içeriye çeşitli nedenlerle yapılan nüfus hareketliliğine ise dış göç denir (Koçak ve Terzi, 2012; Tuna, 1981). İç göçler; mevsimlik göçler, sürekli göçler, emek göçleri, zorunlu ve gönüllü göçler olarak beşe ayrılmaktadır. Dış göçler ise, beyin göçü, işçi göçü ve mübadele göçü olarak üçe ayrılmaktadır. İç göçler daha çok gelişmemiş yerlerden gelişmiş bölgelere olur (Özer, 2004).

\subsection{Göçün Sebepleri}

İtici sebepler; yeni teknolojilerin tarıma giriş, toprak yetersizlik, toprakların bazı nedenlerden dolayı bölünmesi, modern tarım yöntemlerinin kullanılması ve nüfustaki artış olarak sıralanabilir. Bu nedenlerden dolayı köy nüfusu kente göç etmek zorunda kalmıştır (Es ve Ateş, 2004). Siyasi sebepler de itici sebepler arasındadır. Türkiye'de göçe neden olan siyasi sebeplerin başında; devletin uyguladığı iktisadi ve toplumsal politikalar ile terör gelmektedir. Özellikle 1990'ların başından beri Türkiye'nin doğu ve güney kesimlerinde meydana gelen terör hareketleri göç hareketini etkilemiştir. Kırsal kesimde yaşayan insanları itici şekilde göçe sevk eden birçok neden vardır. İtici nedenler, insanların başka yerlere göç etmesine ve başka yerlerden de göç almamasına sebep olmaktadır. İtici güçler arasında aklımıza en temel olarak işsizlik, toprağın verimsizliği, gelirin az olması ve belli coğrafyadaki toprak kavgaları gelmektedir (Çelik, 2006). 
Kırsal kesimden kentsel kesimlere doğru giden ya da gitmeye hazır eden etkenlere cezbeden etkenler denir. İnsanlara çalışma olanağı sunan fabrika ve iş merkezleri belli bölgelerde toplanmıştır. $\mathrm{Bu}$ bölgeler genellikle büyük şehir (İstanbul, Ankara, İzmir, Adana vb.) ve onun çevresinde bulunmaktadır. Bundan dolayı köyden bu bölgelere yoğun bir göç yaşanmaktadır. Ayrıca şehirde kazanılan paranın fazla olması, şehir hayatının daha canlı oluşu, eğitim imkânlarının gelişmiş olması da göçün çekici nedenleri arasındadır ( Es ve Ateş, 2004). Kentteki yaşantı tarzı, insanlara daha çekici gelmektedir. Bu çekici faktörlerin başında, iş imkânları gelmektedir. Bunu dışında ise eğitim, sağlık ve diğer imkânların iyi olması çekiciliği etkilemektedir (Çelik, 2006).

Küreselleşme, beraberinde haberleşme ve ulaşım olanaklarını da geliştirmiştir. Buna paralel olarak dünya küçük bir köy haline gelmiştir. Kırdan kente her yerde insanoğlu dünyadaki olup bitenden haberdar olmaktadır. İletişim imkânlarının hızla artması ve gelişmesi ile köylerden şehirlere göç hareketi artmıştır. Üretim ve hizmetteki gelişimin belli yerlerde toplanması da, köyden şehre göçü arttıran bir diğer cezbedici sebeptir ( Es ve Ateş, 2004).

Yukarıda bahsettiğimiz sebeplerden biri veya birkaçından dolayı insanlar bulunmuş oldukları yerlerden farklı bölgelerden göç etmektedir. Göç olgusuna sadece bir nüfus hareketliliği olarak bakmamak lazım. Kente göç eden insanlar yerleştiği yerde yoksulluk, sağlık, eğitim, barınma dışlanma ve kimlik karmaşasıyla karşı karşıya gelmektedir. Bu durum beraberinde sosyal ve psikolojik sorunlara neden olmaktadır. İnsanların hiç tanımadığı bir yaşam biçimi ile karılaşması, kentlerde istihdam, barınma ve sosyal aidiyetlik duygusundan yoksun olması ve bu durumla baş edememesi kişide travma, stres, uyum sorunu, anksiyete sorunları gibi psikolojik rahatsızlıkları ortaya çıkarmaktadır. Bu durum beraberinde intihar vakalarını getirmektedir (Balcıoğlu ve Samuk, 2002; Ekici, Savaş ve Çıtak, 2001; Polat, 2007; Warfa, Bhui, Craig ve Curtis, 2005).

Türkiye'de yaşanan göçler; sosyo-kültürel, ekonomik ve psikolojik olarak kişiler üzerinde önemli bir etki bırakmıştır. Fakat bu etkiler kişiler tarafından önemli görülmemiştir (Polat, 2007). Fakat yapılan çalışmalar bu durumun ne kadar önemli olduğunu göstermektedir. Fazel ve Stein (2003) yılında yapmış oldukları çalışmada göç eden kişilerin şiddete meyilli olduğu, arkadaşlık ilişkilerinde problem olduğu ve stres bozukluğu olduğu sonucuna ulaşmışlardır. Tuzcu ve Ilgaz (2015) yılında yaptıkları çalışmada ise göç edilen bölgelerin farklı yaşam biçimlerinden dolayı gelen kadınların ruhsal sağlığını olumsuz etkilediği sonucuna ulaşılmışlardır.

Göçün sonuçları özellikle çocukları etkilemektedir. Bu nedenle göçe maruz kalan çocuklar ruh sağlığı açısından büyük bir risk altındadır. Risk altında olan çocuklarda uyum sorunu ve psikolojik rahatsızlıklar ortaya çıkmakta ve bu durum çocuklarda eğitim sorununu beraberinde getirmektedir (Nar, 2008). Mekân olarak ayrılmanın gereği olan göç ile oluşan yeni yaşam olanakları çocukların iç dünyasında psiko-sosyal ve kültürel açılardan ciddi problemlere neden olabilmektedir. Çocuklar doğup büyüdüğü yerlere özlem duymaktadır. Eski yaşam ile yeni yaşam arasındaki farklılık çocukların yalnız kalmasına, ötekileşmesine ve travmatik sonuçlara sebep olmaktadır (Gencer ve Karagöz, 2016). Özen, Antar, Özbulut, Altındağ ve Oto (2001), göçle farklı yerlerden gelen öğrencilerin şiddete maruz kalmasının farklı sorunlar doğuracağı sunucuna ulaşmıştır. Sır ve Özkan (1998) yapmış olduğu çalışmada göç eden çocukların travma oranlarının fazla olduğu sonucuna ulaşmıştır. Aker, Ayata, Özeren, Buran ve Bay (2002) yaptıkları çalışmada işkence mağdurları genelde göç ile gelen kişiler olduğu sonucuna ulaşmışlardır. Dağ, Göktürk ve Türksoy (1998) yılında yapmış oldukları çalışmada da sokak çocukları, çocuk suç oranları ile göç arasında ilişki olduğu sonucuna ulaşılmıştır. Janssen, Verhulst, Bengi-Arslan, Erol, Salter ve Crijnen (2004) yılında yapmış oldukları çalışmada göç ile farklı yerleşim yerlerine giden çocuklar da davranış problemi ortaya çıktı̆̆ sonucuna ulaşmışlardır. Göçle

Anadolu Üniversitesi Ĕ̆itim Fakültesi Dergisi (AUJEF), 5(4), 347-365 
gelen öğrencilerin aileleri okula ilgisiz kalmakta ve öğrencilerini takip etmemektedir. $\mathrm{Bu}$ nedenle öğrenciler derslerinde başarısız olmaktadır (Chimhowu, Piesse ve Pinder 2005). Kaştan ve Bozan (2016)' ya göre; göçle gelen öğrencilerin sosyo-ekonomik sıkıntı, kültür sorunu, davranış bozukluğu ve ailelerin okulla bağının almamasından dolayı derslerde başarısızlardır. Kou (1976), okullar göç ile gelen öğrencileri velilerini belli sorunların görüşülmesi için okula çağırmakta fakat veliler çalıştığı için okula gelmemektedir.

Büyük bir göç hareketliliğine sahip olan İstanbul'da yukarıda bahsedilen problemler gün geçtikçe artmaktadır. Artan bu göç hareketliliği kültürel ve toplumsal dışlanmışlık gibi sosyolojik; davranış ve tavmatik gibi psikolojik sorunları da beraberinde getirmektedir. Ortaya çıkan problemler ise özellikler çocukları eğitim açısından olumsuz etkilemektedir. Bu nedenle göçe bağlı problemlerin ortaya çıkarılıp gerekli tedbirlerin alınması açısından araştırma önem arz etmektedir. Buna paralel olarak araştırmada, göç ile gelen öğrencilerin eğitim sorunlarına ilişkin öğretmen görüşlerinin tespit edilmesi amaçlanmıştır. Amaç doğrultusunda araştırmanın problem cümlesi: Göç ile gelen öğrencilerin eğitim sorunlarına ilişkin öğretmen görüşleri nedir? Araştırmanın alt problemleri ise:

1. Göç ile gelen öğrenciler genel olarak hangi bölgeden gelmektedir?

2. Göç ile gelen öğrencilerin maddi durunu nasıl?

3. Göç ile gelen öğrenciler okula uyum sorunu yaşıyor mu?

4. Göç ile gelen öğrencileri velileri okula gelip öğrenci takibi yapıyor mu?

5. Göç ile gelen öğrencilerin akademik başarıları durumları nasıldır?

6. Göç ile gelen öğrencilerin verilen ödevleri yapıyor mu?

7. Göç ile gelen öğrencilerin davranış durumları nasıldır?

\section{YÖNTEM}

\subsection{Araştırma Modeli}

Araştırma, nitel araştırma yönteminden durum çalışması deseninde tasarlanmıştır. Durum çalışmaları, özellikle değerlendirme süreçleri gibi birçok alanda kullanılan, araştırmacının bir durumu, sıklıkla da bir programı, olayı, eylemi, süreyi ya da bir veya daha fazla bireyi derinlemesine analiz ettiği bir araştırma desenidir. Durumlar zaman ve eylemle sınırlı olup, araştırmacılar uzun bir zaman sürecince çeşitli veri toplama yöntemlerini kullanarak detaylı bilgi toplar (Creswell, 2017).

\section{2. Çalışma Grubu}

Araştırma İstanbul ili Sultanbeyli ilçesi sınırları içerisinde Milli Eğitim Bakanlığı'na bağlı bir ortaokulda yapılmıştır. Araştırmaya, kolay ulaşılabilir durum örneklemesi/uygun örnekleme yoluyla seçilen 35 öğretmen katılmıştır. Bilimsel çalışmalarda daha fazla tercih edilen örnekleme türlerinden biri uygun örneklemedir. Uygun örneklemede, çalışma yapmak için araştırmaya konu olan katılımcılara ulaşması kolaydır. Araştırmaya katılan katılımcılar bu sürece gönüllü olarak katılırlar (Gravetter ve Forzano, 2012). Uygun örnekleme yönteminde araştırmacı yakın olan ve erişilmesi kolay olan bir durumu seçer. Bu örnekleme yöntemi araştırmaya hız ve pratiklik kazandırır (Yıldırım ve Şimşek, 2005). Bu nedenle araştırmaya hız ve pratiklik kazandırmak için araştırmacı tarafından erişilmesi kolay olan örneklem seçilmiştir. 


\subsection{Veri Toplama Araçları}

$\mathrm{Bu}$ araştırmada, veri toplama aracı olarak araştırmacı tarafından hazırlanan yarı yapılandırılmış görüşme formu kullanılmıştır. Yarı yapılandırılmış görüşmeler, hem sabit seçenekli cevaplamayı hem de ilgili alanda derinlemesine gidebilmeyi birleştirir. Bundan dolayı, görüşme, yapılandırılmış ve yapılandırılmamış görüşmelerin faydaları ve dezavantajları bulunmaktadır. Analizlerin kolaylığı, görüşülene kendini ifade etme imkânı, gerektiğinde derinlemesine bilgi sağlama gibi avantajları ve kontrolün kaybedilmesi, önemsiz konularda fazla zaman harcanması, görüşme yapılanlara belli standartlarda yaklaşılmadığından güvenirliğin azalması gibi de dezavantajları bulunur (Büyüköztürk, Çakmak, Akgün, Karadeniz ve Demirel, 2017; Yıldırım ve Şimşek, 2005).

Görüşme formunda ilk olarak temel sorular yazılmıştır. Hazırlanan sorular açık uçlu olarak oluşturulmuştur. Sorular mantıklı bir biçimde düzenlenmiştir. Güvenilir açıklamalar elde etmek için amaca yönelik sorular hazırlanmıştır. Görüşme formu içinde denekleri yönlendirici soru hazırlanmamasına dikkat edilmiştir. Ayrıca alternatif sorular hazırlanarak konuya ait fikirler alınmaya çalış1lmıştır. Görüşme formunda toplam 7 tane soru maddesi yer almaktadır. Formda görüşmeye güven oluşturacak bir giriş hazırlanmıştır. Hazırlanan soru maddeleri uzman görüşüne sunularak son halini almıştır. Görüşme sorularının sorulması sırasında görüşmenin akışına göre gerekli değişiklikler yapılmıştır. Görüşme esnasında teşvik edici olmak ve geri bildirimde bulunmak gerekmektedir. Görüşmede elde edilen veriler ses kayıt cihazı ile kaydedilmiştir. Ses kayıt cihazı ile kaydedilen görüşmeler öncesi görüşülecek olan kişilerden izin alınmıştır. Ses kayıt cihazı ile kaydedilen görüşmeler, araştırmacı açısından önemli avantajlara sahip olduğu için tercih edilmiştir. Görüşme formu içinde çok boyutlu soru sormaktan kaçınılmıştır. Tüm görüşmeciler ile yapılan görüşmeler metin haline getirilmiştir.

\subsection{Verilerin Analizi}

Verilerin analizinde durum çalışmalarında sıkça kullanılan betimsel analiz yöntemlerinden faydalanılmıştır. Betimsel analiz, çeşitli veri toplama teknikleri ile elde edilmiş verilerin daha önceden belirlenmiş temalara göre özetlenmesi ve yorumlanmasını içeren bir nitel veri analiz türüdür. Bu analiz türünde araştırmacı görüştüğü ya da gözlemiş olduğu bireylerin görüşlerini çarpıcı bir biçimde yansıtabilmek amacıyla doğrudan alıntılara sık sık yer verebilmektedir. Bu analiz türünde temel amaç elde edilmiş olan bulguların okuyucuya özetlenmiş ve yorumlanmış bir biçimde sunulmasıdır (Yıldırım ve Şimşek, 2005). Nitel verilerin çözümlenmesi betimsel analizlere (doğrudan alıntılara) uygun olarak yapılmıştır. Her bir bulgu hangi sıklıkla tekrar ettiği(frekansı) bulunmuştur. Böylece, nitel veriler nicel hale dönüştürülmüştür. Burada temel amaç; güvenirliği arttırmak, yanlıllğı azaltmak ve kategoriler arasında karşılaştırmalar yapmaktır (Yıldırım ve Şimşek, 2005). Verilerin analizinde, toplamda ne kadar görüş ifade edildiğinin görülmesi açısından toplam frekanslara yer verilmiştir. Öğretmenlerin her bir soruya verdiği cevaplar ortak kavramlar altında kodlanarak tekrarlanma sıklıklarına göre kendilerine yönlendirilen sorular kategorileştirilerek tablolar halinde sunulmuştur. Araştırmanın gizliliğini ve güvenirliğini korumak adına, öğretmenler (Ö1, Ö2,.. vb.) kodlanmıştır.

\section{BULGULAR}

$\mathrm{Bu}$ bölümde, araştırmada elde edilen veriler doğrultusunda göç eden çocukların eğitim sorunlarına ilişkin öğretmen görüşleri tespit etmeye yönelik bulguları ortaya koymak adına 7 tane açı uçlu görüşme sorusu incelenerek aşağıdaki bulgulara ulaşılmıştır. 
Tablo 2. "Göç İle Gelen Öğrenciler Genel Olarak Hangi Bölgeden Gelmektedir?” Sorusuna İlişkin Öğretmen Görüşleri

\begin{tabular}{lcc}
\hline Bölge & Frekans & Yüzde \\
\hline Doğu Anadolu Bölgesi & 19 & 61,29 \\
Güneydoğu Anadolu Bölgesi & 14 & 45,16 \\
Karadeniz Bölgesi & 6 & 19,31 \\
İç Anadolu Bölgesi & 5 & 16,66 \\
\hline
\end{tabular}

Tablo 2'deki “Göç İle Gelen Öğrenciler Genel Olarak Hangi Bölgeden Gelmektedir?" sorusuna ilişkin öğretmen cevapları incelendiğinde; öğretmenlerin 19'u Doğu Anadolu Bölgesi olarak ifade etmişlerdir. Bu konuya ilişkin Ö11 “...Okulumuza gelen ögrencilerin çoğu Doğu Anadolu Bölgesi'nden gelmektedir. Diğer bölgelerden de var ama en fazla bu bölgeden gelmektedir..." ifadesinde bulunmuştur. Öğretmenlerin 14'ü göçle gelen öğrencilerin Güneydoğu Anadolu Bölgesi'nden geldiğini belirtmiştir. Ö25 konu ile ilgili olarak “... Genelde Güneydoğu Anadolu Bölgesi ve Doğu Anadolu Bölgesi’nden öğrencimiz bulunmaktadır...” ifadesinde bulunmuşlardır. Öğretmenlerin 6's1 öğrencilerin göç ile Karadeniz Bölgesi'nden geldiğini belirtmişlerdir. Konu ile ilgili olarak Ö28 “... Birçok bölgeden ögrenci gelmektedir. Fakat en fazla Doğu Anadolu, Güneydoğu Anadolu ve Karadeniz Bölgesi’nden öğrenci gelmektedir...” ifadesinde bulunmuştur. Öğretmenlerin 5'i ise göç ile gelen öğrencilerin İç Anadolu Bölgesi'nden geldiği cevabını vermişlerdir. Tabloya göre; öğretmenler öğrencilerin hangi bölgelerden göç ettiğine ilişkin farklı cevaplar verse de öğretmenlerin çoğu Doğu Anadolu Bölgesi olarak belirtmiştir. Konu ile ilgili olarak Ö14 “... Öğrencilerimiz $\dot{I}_{C}$ Anadolu Bölgesinden gelmektedir...” ifadesini kullanmıştır.

Tablo 3. “Göç İle Gelen Öğrencilerin Maddi Durunu Nasll?” Sorusuna IIlişkin Öğretmen Görüşleri

\begin{tabular}{lcc}
\hline Maddi Durum & Frekans & Yüzde \\
\hline İyi Değil & 21 & 67,74 \\
Orta & 9 & 29,03 \\
İyi & 1 & 3,22 \\
\hline
\end{tabular}

Tablo 3’teki “Göç İle Gelen Öğrencilerin Maddi Durunu Nasıl?" sorusuna ilişkin öğretmen cevapları incelendiğinde; öğretmenlerin 21'i öğretmen öğrenci ekonomik durumunun iyi olmadığını belirtmişlerdir. Ö6 konu ile ilgili olarak “... Öğrencilerimizin genel olarak ekonomik durumları kötü. Anne baları işsizdir. Bu durum çocuğun başarlsına ve beslenmesine etki etki etmektedir..." ifadesinde bulunmuştur. Ö14 ise konuya ilişkin “... Maddi durumu iyi, orta ve kötü olan ögrencimiz de var. Ama genel olarak maddi sıkıntı yaşayan öğrencimiz çoktur. Bunların ihtiyaçlarını, biz okul olarak ya da gerekli yerlere bildirerek karşılamaya çalışıyoruz..." ifadesinde bulunmuştur. Öğretmenlerin 9'u öğrenci ekonomik durumunun orta olduğunu belirtmişlerdir. Konu ile ilgili olarak Ö16 “... Sinıflar arasında ekonomik olarak büyük uçurumlar var. Bazı sinıflar var ekonomik olarak orta ama çoğu sınıflardaki öğrencilerin ekonomik durumları kötüdür..." ifadesinde bulunmuştur. Öğretmenlerin 1'i ise öğrenci ekonomik durumunun iyi olduğu cevabını vermiştir. Konu ile ilgili olarak Ö20 “... Okula yeni atandı̆̆ım için öğrencilerin ekonomik durumları hakkında fikir sahibi değilim. Sadece sinıf rehberliğini yaptı̆̆ım sınıftaki ögrencilerin ekonomik durumları hakkında bilgim var. Öğrencilerin genel olarak ekonomik durumları iyidir..." ifadesini kullanmıştır. 
Tablo 4. “Göç İle Gelen Öğrenciler Okula Uyum Sorunu Yaşıyor Mu?” Sorusuna İlişkin Öğretmen Görüşleri

\begin{tabular}{lcc}
\hline Uyum Sorunu & Frekans & Yüzde \\
\hline Evet & 26 & 83,87 \\
Hayır & 4 & 12,90 \\
Fikrim Yok & 1 & 3.22 \\
\hline
\end{tabular}

Tablo 4'teki “Göç İle Gelen Öğrenciler Okula Uyum Sorunu Yaşıyor Mu?” sorusuna ilişkin öğretmen cevapları incelendiğinde; öğretmenlerin 26's1 göçle gelen öğrencilerin uyum sorunu olduğu ifade etmişlerdir. Ö1 konu ile ilgili olarak “... Bu sorun ögrencilerde gözle görülür bir şekilde belli olmaktadır. Öğrenciler okula uyum sorunu yaşarken hirçın olmakta ve bu durum bazı davranış problemleri beraberinde getirmektedir...” ifadesinde bulunmuştur. Öğretmenlerin 4'ü göçle gelen öğrencilerin uyum sorunu olmadığ1 belirtmişlerdir. Konu ile ilişkin Ö31 “... Öğrencilerin okula uyumlarında ilk etapta problem olmaktadır. Ama zamanla bu uyum sorunu ortadan kalkmaktadır. Uyum sorunu yaşayan öğrenciler arkadaşları tarafinda soyutlanmaktadır... ” ifadesinde bulunmuştur. Öğretmenlerden 1'i ise göçle gelen öğrencilerin uyum sorunu hakkında fikrinin olmadığ 1 cevabını vermiştir. Konu ile ilişkin Ö20 “... Bu konu hakkında hiçbir fikrim yok. Dediğim gibi okula yeni atamam gerçekleşti. Çevreyi daha yeni tanıyorum. Öğrenci aile yapılarl ve nereden geldikleri hakkında yeni fikir sahibi oluyorum. Bu yüzden öğrencilerimi daha yeni gözlemliyorum...” ifadesinde bulunmuştur.

Tablo 5. “Göç İle Gelen Öğrencileri Velileri Okula Gelip Öğrenci Takibi Yapıyor Mu?? Sorusuna İlişsin Öğretmen Görüssleri

\begin{tabular}{lcc}
\hline Veli Öğrenci Takip Durumu & Frekans & Yüzde \\
\hline Öğrenci Takibi Yapıyor & 5 & 16,13 \\
Öğrenci Takibi Yapmıyor & 26 & 83,87 \\
\hline
\end{tabular}

Tablo 5'teki “Göç İle Gelen Öğrencileri Velileri Okula Gelip Öğrenci Takibi Yapıyor Mu?” sorusuna ilişkin öğretmen cevapları incelendiğinde; öğretmenlerin 26's1 göçle gelen öğrencileri velilerinin okula gelip öğrenci takibi yapmadığını belirtmişlerdir. Konu ile ilgili olarak Ö8 “... Öğrenci velileri bu konuda çok ilgisizdir. Okula gelmeme sebeplerini bilmiyorum ama hiçbir konuda okulumuza uğramıyorlar...” derken Ö15 ise “... Benin gördügü̈m kadarlyla veliler bu konuda çok ilgisiz. Bazı veliler dişında hiçbir veli okula uğrayıp öğrencisinin durumunu sormuyor. Veli, okula sadece ögrenci durumunu sormaya gelmeyip öğretmenlerle tanışmasını $d a$ istiyoruz..." ifadesini kullanmıştır. Öğretmenlerin 5'i ise göçle gelen öğrencilerin velileri okula gelip öğrenci takibi yaptığı cevabını vermiştir. Konuya ilişkin Ö13 “... Çok az veli okulumuza uğrayıp öğrenci ile ilgili yüz yüze bilgi alıyor. Genellikle anne veliler okula gelmektedir. Bu durumu ise babanın işte çalışmasına bağllyorum..." ifadesinde bulunmuştur. 
Tablo 6. "Göç İle Gelen Öğrencilerin Akademik Başarıları Durumları Nasıldı»" Sorusuna İlişkin Öğretmen Görüşleri

\begin{tabular}{lcc}
\hline Akademik Başarı Durumu & Frekans & Yüzde \\
\hline İyi Değil & 18 & 58,07 \\
Orta & 9 & 29,03 \\
İyi & 4 & 12,90 \\
\hline
\end{tabular}

Tablo 6'daki "Göç İle Gelen Öğrencilerin Akademik Başarıları Durumları Nasıldır" sorusuna ilişkin öğretmen cevapları incelendiğinde; öğretmenlerin 18'i göçle gelen öğrencilerin akademik başarı durumlarının iyi olmadığı belirtmişlerdir. Konuya ilişkin Ö22 “... Okulun akademik başarı durumu genel olarak vasatın altında. Ama sınıf bazlı düşündüğümüzde bazı sınıflarda başarıdan söz edebiliriz. Öğrencilerin dersi dinlemiyor, sınavlara çalışmıyor, ödevlerini yapmiyor...” ifadesini kullanmıştır. Öğretmenlerin 9'u göçle gelen öğrencilerin akademik başarı durumlarının orta olduğunu ve 4'ü ise göçle gelen öğrencilerin akademik başarı durumlarının iyi olduğu belirtmişlerdir. Konuya ilişkin Ö29 “... Okulumuzun akademik başarı durumunun iyi olduğunu söyleyemeyeceğim. Orta düzeyde bir başarı vardır. İyi olan ögrencilerimizde var, kötü olan ögrencilerimizde var. Bu durum akademik başarının tam anlamıyla kötü olduğu anlamına gelmemelidir. Yani benim görüşüm orta bir akademik başarı vardır..." ifadesinde bulunmuş̧ur.

Tablo 7. “Göç İle Gelen Öğrencilerin Verilen Ödevleri Yapıyor Mu” Sorusuna İlişkin Öğretmen Görüşleri

\begin{tabular}{lcc}
\hline Ödev Yapma Durumu & Frekans & Yüzde \\
\hline Yapmiyor & 19 & 61,29 \\
Yapıyor & 10 & 32,26 \\
Fikrim Yok & 2 & 6,45 \\
\hline
\end{tabular}

Tablo 7'deki "Göç İle Gelen Öğrencilerin Verilen Ödevleri Yapıyor Mu” sorusuna ilişkin öğretmen cevapları incelendiğinde; öğretmenlerin 19'u göçle gelen öğrencilerin verilen ödevleri yapmadı̆̆ 1 belirtmişlerdir. Konuya ilişkin Ö10 “... Ödevlerini yapan öğrencim de var yamayan öğrencim de. Bazı öğrencilerimin durumu beni çok üzüyor. Çünkü bu öğrencilerimin evlerinde ders çalışma ortamı bulunmuyor. Biz bu konu hakkında okulca toplantı yaptık. Müdür Bey'e gerekli durumu anlattık. Müdürümüz hemen harekete geçti...” ifadesinde bulunmuştur. Öğretmenlerin 10'u göçle gelen öğrencilerin verilen ödevleri yaptığı belirtmişlerdir. Konu ile ilgili olarak Ö17 “... Akademik başarısı iyi olan ögrrencilerimiz ödevlerinin yapma konusunda çok ilgilidir. Ama akademik başarısı iyi olmayan ögrenciler ödev yapma konusunda ilgili değiller...” derken, Ö24 ise “... Ödev konusunda ögrencilerde şunu gözlemledim: Öğrenci derse göre ödev yapıyor. Zorlandiğı derslerin (matematik gibi) derslerin ödevlerini yapmiyorlar. Ama hoşuna giden ya da yapabildiği derslerin ödevlerini yapıyorlar..." ifadesinde bulunmuş̧tur. Öğretmenlerin 2'si ise göçle gelen öğrencilerin verilen ödevleri yapıp yapmama konusunda fikri olmadığı cevabını vermişlerdir. 
Tablo 8. “Göç İle Gelen Öğrencilerin Davranış Durumları Nasıldır” Sorusuna İlişskin Öğretmen Görüşleri

\begin{tabular}{lcc}
\hline Davranış Durumu & Frekans & Yüzde \\
\hline Okul Eşyasına Zarar Veren & 17 & 54,84 \\
Dersin İşlenişini Bozan & 15 & 48,39 \\
Arkadaşlarına Şiddet Uygulayan & 10 & 32,26 \\
İçine Kapanık & 5 & 16,13 \\
\hline
\end{tabular}

Tablo 8'deki "Göç İle Gelen Öğrencilerin Davranış Durumları Nasıldır" sorusuna ilişkin öğretmen cevapları incelendiğinde; öğretmenlerin 17'si göçle gelen öğrencilerin okul eşyasına zarar verdiği belirtmişlerdir. Konu ile ilgili olarak Ö19 “... Göçle gelen bazı ögrrencilerim dersin huzurunu bozmaktadır. Ben derse girdiğimde hemen ögrrencilerden şikâyetler başlıyor. Öğretmenim şu çocuk masayı kırdı, ögretmen masasına su döktü gibi...” ifadesinde bulunmuştur. Öğretmenlerin 15'i göçle gelen öğrencilerin dersin işlenişini bozduğu belirtmiştir. Konu ile ilgili olarak Ö19 “... Göçle gelen bazı ögrencilerim dersin huzurunu bozmaktadır. Ben derse girdiğimde hemen öğrencilerden şikâyetler başllyor. Öğretmenim şu çocuk masayı kırdl, öğretmen masasına su döktü gibi...” ifadesinde bulunmuştur. Öğretmenlerin 10'u göçle gelen öğrencilerin arkadaşlarına şiddet uyguladığını belirtmişlerdir. Konu ile ilgili olarak Ö2 “... Çok efendi öğrencilerim de var. Ama çoğu sanki psikolojisi bozuk gibi davranıyor. Arkadaşlarına argo kelimeler söyleyen öğrencilerimiz var. Bu yapıya sahip öğrenciler için toplantılar düzenleyip gerekli önlemleri almaya başladık. Çünkü bölgemiz devamlı göç alan bir yerdir. Neredeyse her dönem sınıfa yeni ögrenciler ekleniyor. Bu durum davranış problemlerini beraberinde getirmektedir. Biz okul olarak bu durumun önüne geçmek için acil planlar devreye sokuyoruz..." ifadesinde bulunmuştur. Öğretmenlerin 5'i ise göçle gelen öğrencilerin içine kapanık olduğu cevabını vermişlerdir. Konu ile ilgi olarak Ö23 “... Bu tip ögrrencilerin davranış durumlarında sorun olduğu gördüm. Bu ögrenciler ya arkadaşlarıyla kavga ediyor ya da içine kapanık oluyor..." ifadesinde bulunmuştur.

\section{TARTIŞMA ve SONUÇ}

$\mathrm{Bu}$ bölümde, araştırma soruları 1şı̆̆ında analizler yapılarak sonuçlara ulaşılmıştır. Bulunan sonuçlar alan yazıya dayalı olarak tartışılmıştır.

Araştırmaya katılan öğretmeler, göçle gelen öğrencilerin genelde Doğu ve Güneydoğu Anadolu Bölgesi'nden geldiğini belirtmiştir. Demir, Yaşa ve Dağdemir (2013) yılında yaptıkları çalışmada; en fazla göç alan bölge Marmara bölgesi; en fazla göç veren bölge ise Doğu ve Güneydoğu Anadolu olduğu sonucuna ulaşmışlardır. Iş̧1k (2009) yılında yaptı̆̆ çalışmada ise, İstanbul, Ankara ve İzmir gibi büyük şehirler göç alırken, Erzurum, Van, Muş, Bingöl, Artvin gibi iller de göç verdiği sonucuna ulaşmıştır. Bu sonuçlar, araştırmanın sonucu ile örtüşmektedir.

Araştırmaya katılan öğretmenler, göçle gelen öğrencilerin çoğunun maddi durumunun iyi olmadığını belirtmiştir. Butler ve Weatherley (1992) yılında yaptıkları çalışmada, çocuklar için ailenin maddi durumun iyi olmasının önemine vurgu yapılmıştır. Bu bağlamda göç eden çocukların ekonomisinin iyi olmaması göçün temel sorunu olarak ifade edilmiştir. Gencer (2017) ve Şeker, Tunç ve Şahin (2010) yapılan çalışmalarda; göç eden ailelerin çok çocuklu olası nedeniyle çoğunun ekonomik durumunun olamadığı gözlemlenmiştir. Altıntaş (2012) yılında yaptığı çalışmada ise; göçle gelen ailelerin ekonomik düzeylerinin iyi olmaması eğitimde önemli bir sorun olarak görmüştür. 
Araştırmaya katılan öğretmenler, göçle gelen öğrencilerin çoğunun okula uyum sorunu yaşadığını belirtmiştir. Öğretmenler, okula uyum sorunu yaşayan öğrencilerde "arkadaşları tarafindan soyutlanma" ve "hırçın davranma ve bu durumun bazı problemlere sebep olma" gibi problemleri beraberinde getirdiğini belirtmiştir. Yaşanan göçler nedeniyle öğrenciler çevreye, okula, arkadaşlarına ve öğretmenlerine belirli bir süre uyum sağlayamamaktadır. Bu durum öğrencilerde başta akademik başarı olmak üzere çeşitli problemler ortaya çıkarmaktadır (Tezcan, 1994). Chikkatur (2009) ve Cazares (2009) yaptıkları çalışmalarda; göçle birlikte çocuklar uyum, dil, dışlanma ve aidiyet sorunlarıyla karşılaştığı belirtmişlerdir. Ekici (2015) yılında yapmış olduğu çalışmada; okul ve çevreye uyum güçlüğü, düşük akademik başarı, dışlanma, şiddet, ayrımcılık ve aidiyet eksikliği çocukların göçle birlikte yaşadığı eğitim sorunları olduğu sonucuna ulaşmıştır. Topsakal, Merey ve Keçe (2013) yaptıkları çalışmada; göçle birlikte öğrencilerde yeni çevre uyum konusunda çeşitli problemler ortaya çıktığı; Bahar ve Yılmaz (2018) yılında yaptıkları çalışmada ise; göçle gelen öğrenciler arkadaşlık sürecine katılamadığı ve bu durumun böyle olmasında kendinin payı olduğu ifade ettiği sonucuna ulaşılmıştır. Ayrıca; (Avcı, Koçoğlu ve Ekici, 2013; Han, 2010; Kaştan, 2015; Mercan, Polat Uluocak, 2009; Uzun ve Bütün, 2016) yılında yaptıkları çalışma sonuçları da göçle gelen öğrencilerin okula uyum sorunu yaşaması bağlamında araştırmanın sonuçlarını desteklemektedir. İç göçlerle birlikte eğitim öğretim ortamlarında olumsuz durum meydana gelmektedir. İç göçlerle gelen ilköğretim ve ortaöğretim öğrencilerinde akademik ve sosyal problemler göze çarpan sonuçlar arasındadır (GEM, 2019; Özyılmaz, 2018; Schreglmann, 2020)

Araştırmaya katılan öğretmenler, göçle gelen öğrenci velilerinin çoğunun okula gelip öğrenci takibi yapmadığını belirtmiştir. Bu durumla ilgi olarak öğretmenler, "öğrenci velilerinin bu konuda çok ilgisiz olduğunu" belirtmiştir. Ancak öğretmenler, çok az velinin okula uğrayıp öğrenciyi takip ettiğini belirmiştir. Bu durumu öğretmenler, "genelde anne velilerin duyarl olduğu ve okula haftanın belli günlerinde gelip öğrencisinin durumunu sorduğu" şeklinde ifade etmiştir. Altıntaş (2012) y1lında yaptığı çalışmada, ailelerin yapısı ve ilgisizliğinden dolayı öğrenciyi takip etmemesi öğrenci başarısını olumsuz etkilemektedir. Benzer çalışmada; Topsakal vd. (2013) göç eden ailelerin eğitime ilgi göstermeyip geçim derdine düştügünü belirtmiştir. Karakuş (2006) çalışmada da velilerin öğrenci durumlarını takip etmemesinden dolayı öğrenci başarısının düşmesi açısından araştırmayla benzer sonuca ulaşılmıştır.

Araştırmaya katılan öğretmenler, göçle gelen öğrencilerin çoğunun akademik başarı durumunun iyi olmadığını belirtmiştir. Bu durumla ilgili olarak öğretmenler, "öğrenci akademik başarısının iyi olmadığı ve bu yüzden dersleri dinlemeyip slnavlara çalışmadı̆̆ ve ödevlerini yapmadĭ̆ını" ifade etmişlerdir. Ancak öğrenci başarı durumları iyi olanlarla ilgili olarak öğretmenler, " genel bir başarı değil sınıf bazlı başarı olduğunu” belirtmiştir. Nar (2008) yılında yapmış olduğu çalışmada, göçle gelen öğrencilerin ailelerinin eğitim seviyesi düşüklüğü ve ekonomik durumlarının iyi olmamasında dolayı çocuklarını okutmak istemediği ve bu durumun öğrenicinin akademik başarısını olumsuz etkilediği sonucuna ulaşmıştır. Avcı, Koçoğlu ve Ekici (2013); yaptıkları çalışmada; anne babanın eğitim seviyesinin düşük olması ve derslerinde yardımcı olacak kimsenin olmaması öğrencilerin akademik başarısını düşürdüğü belirtmişlerdir. Ayrıca çalışmada, ailenin geçim derdinde olması öğrenci ile ilgilenememesi öğrenci akademik başarısını düşürdüğü sonucuna ulaşılmıştır. Bozan ve Kaştan (2018) yılında yaptıkları çalışmada; öğrencilerin yeni geldikleri okulda bazı uyum problemi yaşadıkları bu durumun öğrencilerin akademik başarılarına etki ettiği ifade etmişlerdir. Küçükali ve Çevik (2018) yılında yapmış oldukları çalışmada ise, öğrencilerin yeni taşındıkları bölgelere uyum sorunu yaşadıkları ve bu durumun öğrencide bazı problemlere sebep olduğu sonucuna ulaşılmıştır. Özellikle ergenlik çağında olan çocukların ve gençlerin kentlere göç ettikten sonra kimlik bunalımı 
yaşamaları, sosyal dışlanmış hissetmeleri, suç işlemeye ve madde bağımlılığına yönelmeleri belli başlı problemler arasında gelmektedir (Sevinç, Davran ve Sevinç, 2018). Yapılan bu çalışmalar araştırmanın sonucu ile paralellik göstermektedir.

Araştırmaya katılan öğretmenler, göçle gelen öğrencilerin çoğunun verilen ödevleri yapmadığını belirtmiştir. Bu durumla ilgili olarak öğretmenler, "öğrencilerin evlerinde uygun koşullar olmadı̆̆ $\imath$ " ve "bazı dersleri sevmediği " için ödevlerini yapmadığını belirtmiştir. Bozan ve Kaştan (2018) yılında yaptıkları çalışmada, göçle gelen öğrencilerin kardeş sayısının fazla olmasından dolayı ödevlerini yapmadığı ve öğretmeniyle sorun yaşadığı; okulda arkadaşı olmadığ için yalnızlık yaşamasının derslerini olumsuz etkilediği sonucuna ulaşmışlardır. Bu sonuç araştırmanın sonucu ile benzerlik göstermektedir.

Araştırmaya katılan öğretmenler, göçle gelen öğrencilerin çoğunda davranış bozukluğu olduğunu belirtmiştir. Öğretmenler, öğrenci davranış durumlarını, "okul eşyalarına zarar verme", "dersin işleyişini bozma", "arkadaşlarına şiddet uygulama" ve "içine kapanık olama" olarak belirtmiştir. Tok (2010) yılında yaptığı çalışmada, göçle gelen öğrencilerin arkadaşlarıyla ve öğretmenleriyle iletişim problemleri olduğunu belirtmiştir. Okulda iletişim sorunu yaşayan öğrencinin kendini ispatlamak için sık sık kavga ettiği, delici ve kesici alet kullandığ 1 ve disiplinsiz hareketlerde bulunduğu sonucuna ulaşmıştır. Öngören, Özkan, Yüksel ve Sever, (2017) yaptıkları çalışmada; göçle gelen öğrenciler arkadaşları tarafında dışlanıp alay edildiği için psikolojik olarak olumsuz etkilenmekte bundan dolayı kavga ve küfür gibi disiplin problemlerine karıştığ 1 belirtmişlerdir. Nar (2008) yılında yaptı̆̆ çalışmada ise; göçle gelen öğrencilerin kıyafetlerinin özensiz olduğu davranışlarında ve konuşmalarında sorun olduğu sonucuna ulaşmıştır. Ayrıca; (Altıntaş, 2012; Bahar ve Yılmaz, 2018; Bozan ve Kaştan, 2018; Mercan vd., 2016) yaptıkları çalışmalar araştırma sonuçlarıyla benzerlik göstermektedir.

Araştırma sonuçlarından yola çıkarak aşağıdaki önerilere yer verilmiştir.

1. Göçle gelen öğrencilerin çoğunun maddi durumu iyi değildir. Bu doğrultuda hükümet politikaları geliştirilip bölgeler arası ekonomik farklılıklar azaltılarak göçün önüne geçilebilir. $\mathrm{Bu}$ sayede aileler ekonomik sıkıntı yaşamayıp göç etmeyecektir. Öğrenciler ise maddi olarak sıkıntı yaşamayacaktır.

2. Göçle gelen öğrencilerin çoğu okula uyum sorunu yaşamaktadır. Öğrencilerin uyum sorunu yaşamaması için okullarda göçle gelen öğrencilere dönük proje ve programlar geliştirilebilir.

3. Göçle gelen öğrenci ailelerinin çoğu okula gelip öğrencileri takip etmemektedir. Bu doğrultuda ailelerin okula gelme bilincini arttırmak için veli ziyaretleri ve veliyi okula getirecek çalışmalar yapılabilir.

4. Göçle gelen öğrencilerin akademik başarı durumları genel olarak iyi değildir. Ayrıca, bu öğrenciler ödevlerini yapmamaktadırlar. Öğrenciler için kurslar yapılabilir. Ek çalışma ödevleri verilip takibi yapılabilir. $\mathrm{Bu}$ öğrencilerin akademik başarısını geliştirecek ve onları motive edecek ödüller verilebilir. Yarışmalar ve geziler düzenlenebilir.

5. Göçle gelen öğrencilerde genel olarak davranış bozukluğu bulunmaktadır. Bu tarz öğrenciler için okullarda kuralları daha belirgin hale getirilerek kontrol altına alınabilir. Disiplin problemleri sonunda ne gibi bir problemle karşılaşacağı öğrenciye hissettirecek çalışmalar okullarda yaygınlaştırılabilir. 
6. Türkiye'de göç önemli bir olgudur. Bu bağlamda göçün yoğun olarak yaşandığı bölgelerde Milli Eğitim Bakanlığı okul ve programları tekrardan gözden geçirmelidir. Göçle gelen öğrencilerin ihtiyaçları göz önünde bulundurularak gerekli çalışmalar yapılmalıdır. 


\section{KAYNAKLAR}

Aker, T., Ayata, B., Özeren, M., Buran, B. \& Bay, A. (2002). Zorunlu iç göç: Ruhsal ve toplumsal sonuçları. Anadolu Psikiyatri Dergisi, 3(2), 97-103.

Altıntaş, E. (2012). İdareci, öğretmen ve öğrencilerin görüşlerine göre iç göçün yaşandığı bölgelerdeki ilköğretim okullarında eğitim öğretim sürecinde karşlaşılan sorunlar (Esenyurt Örneği). Yayınlanmamış Yüksek Lisans Tezi, Gazi Üniversitesi Eğitim Bilimleri Enstitüsü Eğitim Bilimleri Ana Bilim Dalı, Ankara.

Avc1, Y. E., Koçoğlu, E. \& Ekici, Ö. (2013). Göçün eğitim ve eğitim yönetimine etkisine ilişskin okul yöneticilerinin görüşleri (Diyarbakır örneği). International Journal Of Social Science (Jass), 6(2), 91-105.

Bahar, H. H., \& Yılmaz, O. (2018). Ahıska, göç ve eğitim. Eğitimde Nitel Araştırmalar Dergisi, 6(2), 238-257.

Balcıoğlu, İ. \& Samuk F. (2002). Göç ve ruh sağlığımız. Ed: İ. Balcıŏglu, Medikal ve Psikososyal Açıdan Göç Olgusu. İstanbul, Alfabe Basım Yayın.

Bozan, İ. \& Kaştan, Y. (2018). Göç yaşamış öğrencilerin karşılaştıkları sorunlara ilişkin görüşleri: bir durum çalışması. Uluslararası Sosyal ve Eğitim Bilimleri Dergisi, 5(10), 225-248.

Butler, S. \& Weatherley, R. (1992). Orta yaştaki yoksul kadınlar ve ihmal kategorileri. Sosyal Hizmet, 37(6), 510-515.

Büyüköztürk, Ş., Çakmak, E. K., Akgün, Ö. E., Karadeniz, Ş., \& Demirel, F. (2017). Bilimsel araştırma yöntemleri. Pegem Atıf İndeksi, 1-360.

Cazares, L., R., A. (2009). Comperative study of average and high-achieving high school immigrant and non1mmigrant students of Mexican heritage. Unpublished Master's Thesis, University of Southern California, Goodburn.

Chımhowu, A., Jenifer, P., \& Caroline, P. (2005). The socioeconomic impact of remittances on poverty reduction, Remittances: Development Impact And Future Prospects, Samuel Munzele Maimbo ve Dilip Ratha (ed.), The World Bank, Washington DC.

Chikkatur, A., P. (2009). Difference matters: Race, immigration and national identity. At A Diverse, Urban Public High School. Unpublished Master's Thesis, University of Pennsylvania.

Creswell, J. W. (2017). Araştırma deseni. (Çev Edt: Demir, S. B.). Ankara: Eğiten Kitap.

Çakır, S. (2011). Türkiye'de göç kentleşme/gecekondu sorunu ve üretilen politikalar. SDÜ Fen Edebiyat Fakültesi Sosyal Bilimler Dergisi, (23).

Çelik, F. (2006). İç göçlerin itici ve çekici güçler yaklaşımı ile analizi. Erciyes Üniversitesi İktisadi ve İdari Bilimler Fakültesi Dergisi, (27).

Dağ, R., Göktürk, A., \& Türksoy, H. C. (1998). Bölge içi zorunlu göçten kaynaklanan toplumsal sorunların Diyarbakır kenti ölçeğinde araştırılması. TMMOB yayınları: Ankara.

Demir, N., Yaşa, S., \& Dağdemir, V. (2014). Düzey 1 bölgelerine göre yoksulluk ve göç durumu. Atatürk Üniversitesi Ziraat Fakültesi Dergisi, 44(1), 99-102.

Ekici, F. Y. (2015, Mayıs). Çocukların göçle birlikte yaşadıkları eğitim sorunları üzerine bir inceleme. Disiplinlerarası göç sempozyumu, Sabahattin Zaim Üniversitesi, İstanbul.

Ekici, G., Savaş H. A. \& Çıtak S. (2001). İntihar riskini arttıran psikososyal etmenler (sosyal güvence yokluğu, göç ve diğer stresörler). Anadolu Psikiyatri Dergisi, 2(4) 204-212. 
Es, M., \& Ateş, H. (2004). City management, urbanization and migration: problems and solution proposals. Journal of Social Political Conferences, (48) (pp. 205-248).

Fazel, M., \& Stein, A. (2003). Mental health of refugee children: comparative study. Bmj, 327(7407), 134.

GEM (Global Education Monitoring Report) (2019). Küresel eğitim izleme raporu: göç, yerinden edilme ve eğitim: Duvarlar yerine köprüler inşa etmek. United Nations Educational Scientific And Cultural Organisation.

Gencer, T. E. (2017). Göç ve eğitim ilişkisi üzerine bir değerlendirme: suriyeli çocukların eğitim gereksinimi ve okullaşma süreçlerinde karşılaştıkları güçlükler. Journal of International Social Research, 10(54), 838-851.

Gencer, T. E. \& Karagöz, D. (2016). Mülteci çocukların mekansal ve psiko-sosyal yoksunlukları: kentsel alanlarda mülteci çocuk olmak. (Ed. A. Çolpan Kavuncu), Kentsel Güvenlik ve Çocuk Suçluluğu, Ankara: Polis Akademisi Yayınları, ss. 37-46.

Gravetter, J. F. \& Forzano, L. B. (2012). Research methods for the behavioral sciences. USA: Linda SchreiberGanster.

Güreşçi, E. (2010). Köyden kente göçün köydeki ve kentteki yansımaları: Akpınar köyü üzerine bir değerlendirme. Sosyal ve Beşeri Bilimler Dergisi, 2(2), 47-55.

Han, T. (2010). Göç eden ailelerin çocuklarının eğitim ve öğretimde karşılaştıkları uyum sorunları (Yayımlanmamış Yüksek Lisans Tezi). Ankara Üniversitesi, Ankara.

Işık, Ş. (2009). Türkiye'de eğitim amaçlı göçler. Coğrafi Bilimler Dergisi, 7(1), 27-37.

İçduygu, A. \& Ünalan, T. (1998). Türkiye'de İçgöç: Sorunsal Alanları ve Araştırma Yöntemleri. Türkiye'de İç göç. İstanbul: Tarih Vakfı Yayınları.

Janssen, M. M., Verhulst, F. C., Bengi-Arslan, L., Erol, N., Salter, C. J., \& Crijnen, A. (2004). Comparison of self-reported emotional and behavioral problems in Turkish immigrant, Dutch and Turkish adolescents. Social Psychiatry and Psychiatric Epidemiology, 39(2), 133-140.

Kaştan, Y. (2015). Türkiye göç yaşamış çocukların eğitim sürecinde karşılaşılan problemler. Uluslararası Sosyal Ve Eğitim Bilimleri Dergisi, 4(2), 216-229.

Kaştan, Y. \& Bozan, İ. (2016). Yöneticiler açısından göçün eğitim üzerindeki etkisi: bir durum çalışması. Uluslararası Sosyal ve Eğitim Bilimleri Dergisi, 3(5), 105-129.

Koçak, Y. \& Terzi, E. (2012). Türkiye'de göç olgusu, göç edenlerin kentlere olan etkileri ve çözüm önerileri. Kafkas Üniversitesi İktisadi ve İdari Bilimler Fakültesi Dergisi, 3(3), 163-184.

Koyuncu, A. (2011). Anadolu kentlerinde göç: Konya örneği. NEÜ Sosyal Bilimler Enstitüsü Dergisi, 1.

Kuo, W. (1976). Theories of migration and mental health: an empirical testing on Chinese-Americans. Social Science \& Medicine, 10(6), 297-306.

Küçükali, R. \& Çevik Özdemir, H.N. (2018). Göç etmiş ailelerin ilköğretim çağındaki çocuklarının yaşadıkları sorunların değerlendirilmesi, Atatürk Üniversitesi Sosyal Bilimler Enstitüsü Dergisi, 22, 2149-2158.

Mercan Uzun, E. \& Bütün, E. (2016). Okul öncesi eğitim kurumlarındaki Suriyeli Sığınmacı çocukların karşılaştıkları sorunlar hakkında öğretmen görüşleri. Uluslararası Erken Çocukluk Eğitimi Çalışmaları Dergisi, 1(1), 72-83.

Nar, B. (2008) Göçün eğitime ve eğitim yönetimine etkileri(dilovası örneği). Yayımlanmamış Yüksek Lisans Tezi, Sakarya Üniversitesi Sosyal Bilimler Enstitüsü, Sakarya. 
Öngören, S., Özkan, A., Yüksel, B. \& Sever, D. (2017). Göçmen çocukların yaşadıkları uyum problemlerinin öğretmen görüşleri açısından incelenmesi. Akademik Sosyal Araştırmalar Dergisi, 5(59), 147-159.

Özcan, Y., Z. (1998). İç göçün tanımı ve veriler ile ilgili bazı sorunlar. Konferans: Türkiye’de iç göç; 6-8 Haziran 1997, İstanbul, Tarih Vakfı Yayınları.

Özen, Ş., Antar, S., Özbulut, Ö., Altındağ A. \& Oto R. (2001). İç göç yaşayan bir grup lise öğrencisinde ruhsal belirti şiddetinin cinsiyet ile ilişkisi. Çocuk ve Gençlik Ruh Sağlığı Dergisi, 8(3), 156-162.

Özer, İ. (2004). Kentleşme, kentlileşme ve kentsel değişme. Bursa. Ekin Kitabevi.

Özyılmaz, A. (2018). İç göçlerin bölgesel dengesizlik üzerindeki etkisi: Türkiye örneği. Yayınlanmamış Doktora Tezi. İstanbul Üniversitesi Sosyal Bilimler Enstitüsü İktisat Anabilim Dalı. İstanbul.

Polat, G. (2007). İç göçün çocuk ruh sağlığına etkisi ve sosyal hizmet müdahalesi. Toplum ve Sosyal Hizmet, 18(1), 89-106.

Polat Uluocak, G. (2009). İç göç yaşamış ve yaşamamış çocukların okulda uyumu. Dokuz Eylül Üniversitesi Buca Eğitim Fakültesi Dergisi, 26, 35-44.

Schreglmann, S. (2020) İç göç ve eğitim ilişkisi. (Ed. R. Demir), Çeşitli Açılardan Göç Ve Eğitim: Multidisipliner Bir Çalışma, Ankara: İksad Yayinevi, ss. 31-58.

Sevinç, G., Davran, M. K. ve Sevinç, M. R. (2018). Türkiye'de kırdan kente göç ve göçün aile üzerindeki etkileri. İktisadi İdari ve Siyasal Araştırmalar Dergisi, 3(6), 70-82.

Sır A, Bayram Y. \& Özkan M.(1998). Zorunlu iç göç yaşamış bir grupta travma sonrası stres bozukluğu üzerine bir ön çalışma. Türk Psikiyatri Dergisi, 9(3), 173-180.

Şeker, B. D., Tunç, A. İ. \& Şahin, E. (2010). Van ili örneğinde terör suçlarına karışan kişilerin iç göç, sosyal psikolojik ve eğitim açılarından değerlendirilmesi. Terörün Sosyal Psikolojisi, 229-253.

Taşçı, F. (2009). Bir sosyal politika sorunu olarak göç. Kamu-İş Dergisi, 10(4).

Tekeli, İ. (1998). Türkiye'de iç göç sorunsalı yeniden tanımlanma aşamasına geldi. Konferans: Türkiye'de iç göç; 6-8 Haziran 1997, İstanbul, Tarih Vakfı Yayınları.

Tezcan, M. (1994). Ülkemizde göç ve eğitim sorunları. Ankara Üniversitesi Eğitim Bilimleri Fakültesi Dergisi, $27(1), 61-67$

Tok, N. (2010). Göç alan okullarda ilköğretim 4. ve 5. sınıf öğrencileri rehber öğretmen ve sınıf öğretmenlerinin görüşlerine göre öğrenme güçlüklerinin incelenmesi. Yayınlanmamış Yüksek Lisans Tezi. Mersin Üniversitesi Sosyal Bilimler Enstitüsü, Mersin.

Topsakal, C., Merey, Z. \& Keçe, M. (2013). Göçle gelen ailelerin çocuklarının eğitim öğrenim hakkı ve sorunları üzerine nitel bir çalışma. Uluslararası Sosyal Araştırmalar Dergisi, 27(6), 546-560.

Tuna, K. (1981). Yurt dışına işçi gönderme olayının sosyolojik eleştirisi. İstanbul: İstanbul Üniversitesi Edebiyat Fakültesi Basımevi.

Tuzcu, A., \& Ilgaz, A. (2015). Göçün kadın ruh sağlığı üzerine etkileri. Psikiyatride Güncel Yaklaşımlar, 7(1).

Yamak, R. \& Yamak, N. (1999). Türkiye’de gelir dağılımı ve iç göç. Dokuz Eylül Üniversitesi Sosyal Bilimler Enstitüsü Dergisi, 1(1).

Yenigül, S., B. (2005). Göçün kent mekânı üzerine etkileri. G.Ü. Fen Bilimleri Dergisi, 18(2).

Yıldırım, A. (2014). Kırsaldan kente göç ve değişen siyaset: Muş örneği. Karamanoğlu Mehmetbey Üniversitesi Sosyal Ve Ekonomik Araştırmalar Dergisi, 3, 25-32. 
Yıldırım, A. \& Şimşek, H. (2005). Sosyal bilimlerde nitel araştırma yöntemleri. Ankara: Seçkin.

Warfa, N., Bhui, T., Craig, T. \& Curtis, S. (2005). Post-migration geographical mobility, mental health and health service utilisation among Somali refugees in the UK: a qualitative study. Health Place, 12, 503-515. 


\section{EXTENDED ABSTRACT}

Shaping the social and economic structure of the country's migration in Turkey is one of the basic elements. The occurrence of this situation does not depend on a single cause, but rather multiple reasons have an impact on the formation of this structure. Indeed, after 1950, urbanization and internal migration gained great momentum in parallel with the social change process in question. According to this, in terms of our country, it can be said that the post-migration movement was the determinant of 1950 and 1980. Political, social and economic developments that took place at those dates have been decisive in shaping the migration movement.

Socio-cultural migration that took place in Turkey, has left a significant impact on people economically and psychologically. However, these effects were not attracted by individuals. In the studies carried out, they concluded that the immigrants would tend to be violent, they would have problems with friendships and they would have stress disorder.

The consequences of migration affect particularly children. Therefore, children exposed to migration are at great risk of losing their mental health. Adaptation problems and psychological disorders arise in children at risk, and this raises educational problems for children. New living spaces created by immigration, which is a necessity to leave as a place, can cause serious problems in the inner world of children in terms of psycho-social and cultural aspects. Children miss the places where they were born and raised. The difference between the old life and new life causes children to be alone, otherized and traumatic results. The exposure of students from different places to violence causes different problems. Families of migrant students are not interested in school and do not follow their students. For this reason, students fail in their classes. Due to socio-economic problems, cultural problems, behavioral disorders, families do not get connected with school and students fail in lessons. Schools call their parents to come to school to discuss certain problems, but they do not come to school because of their jobs.

The aforementioned problems are increasing day by day in Istanbul, which experiences a great migration movement. For this reason, research is important in terms of revealing these problems and taking necessary measures. In parallel with this study, it was aimed to determine the opinions of the teachers about the education problems of the migrant students.

The research is designed in a case study pattern as a the qualitative research method. The research was carried out in a secondary school affiliated with the Ministry of Education within the borders of Sultanbeyli district of Istanbul. 35 teachers selected through easy-access case sampling / proper sampling participated in the study. In this study, a semi-structured interview form prepared by the researcher was used as data collection tool. Basic questions were first written in the interview form. The questions were created as open-ended. The questions were arranged logically. Purposeful questions were prepared to obtain reliable explanations. In the interview form, attention was paid not to prepare questions that direct the subjects. In addition, alternative questions were prepared and the students' ideas were tried to be obtained. There are 7 question items in the interview form. In the form, an introduction was prepared to give information about the interview. The items were presented to the expert opinion and took their final form. During the interrogation of the interview questions, the necessary changes were made according to the flow of the interview. It is necessary to be encouraging and give feedback during the interview. The data obtained in the interview were recorded with a voice recorder. Permission was obtained from participants to be interviewed before the interviews were recorded with the voice recorder. The interviews were preferred to be recorded with the voice recorder

Anadolu Üniversitesi Ĕ̈itim Fakültesi Dergisi (AUJEF), 5(4), 347-365 
because they had important advantages for the researcher. Multidimensional questions were avoided within the interview form. Interviews with all interviewees were transcribed. Descriptive analysis methods, which are frequently used in case studies, were used to analyze the data.

The teachers participating in the study stated that the migrant students generally came from the Eastern and Southeastern Anatolia Region, that most of them were not in a good financial situation, their parents did not follow the school, their academic success was not good, they did not do their homework and most of them had a behavioral disorder. 